西ヨーロッパの地域開発一北海道開発を考えつつ一

\title{
Regional Development in Europe and Its Implication for Hokkaido
}

\author{
中 村 英 夫**
}

\section{By Hideo NAKAMURA}

\section{1. はしがき}

高度福祉国家より成り, 世界で最む安定した地域 と見なされている西ヨーロッパもその内部には大き な地域格差が存在し, 種々の地域開発課題をかかえ ている. 本稿ではそこにみるこれらの課題とそれに 対する取り組みを, 特に北海道の地域開発を念頭に おきつつ概略述べてみることにしたい，西ヨーロッ パのいくつかの地域は寒冷な気候や, やせた土埪の 地域, 石炭, 鉄鋼など構造不況産業をむつ地域, 東 ブロック諸国に接する场境地域や島しょ地域, 等々, 北海道にきわめて類似した状況にある.したがって そてでの試みをみることは, 成功例であれ, あるい はネガティブな評価のあのであれ, それは北海道開 発の方策を改めて考える機会と, その際の参考にな ると考えるのである.

\section{2. 西ヨーロッパ}

ヨーロッパは東はボスポラス海峡を隔ててアジア に対峙するトルコのイスタンブールから西は北大西 洋上の火山国アイスランドまで, 北は北極圏のラッ プランドから, 南は海狭を隔ててアフリカのモロッ

*キーワード: 地域開発, ヨーロッパ, 北海道

**正会員 工博 東京大学教授 工学部土木工学科
コに向かい合うスペインのジブラルタルまでの広大 な地域であり, 広義の西ヨーロッパとはその中の自 由主義体制国家群を指すのが一般的である。しかし， この西ヨーロッパといえぞ，その中の国々は人種的, 言語的, 歴史的, 文化的, 政治的, 経済的にきわめ て多様であり, これらを一つにしてそこでの地域開 発を論じるのは不可能であり，また，無意味でああ る.そのためてれらの国々の中であ社会経済的にみ てわが国に比較的近い, 西ヨーロッパのほぼ中央部 にある国々, すなわち 1971 年以前に加盟した EC 8 か国とスイス,オーストリヤを含む地域を対象と して論ずることにする，乙れらの国々を総称する適 切な名称がないので，以下では西ヨーロッパという 名称でこれらの地域を指すととにする。

図ー 1 は西ヨーロッパの各国を示した地図に日本 を重ねたすのである、ヨーロッパの大半が日本より ずっと北に位置し, 北海道といえどスイスより南が ほとんどであり，札幌は南ドイッのミュンヘンより 緯度では $5^{\circ}$ も南に位置していることがわかる。し かしメキシコ湾流の影響を大きく受ける西ヨーロッ パと親潮やシベリヤ寒気団の影響下にある北海道で は気候的には前者が, 特に海岸部ではより温和であ るといえる。

図一 2 は西ヨーロッパ各国と日本全体, 北海道の 面積, 人口を図ー3 は 1 人当たり GNP と一次産業就 
中村:

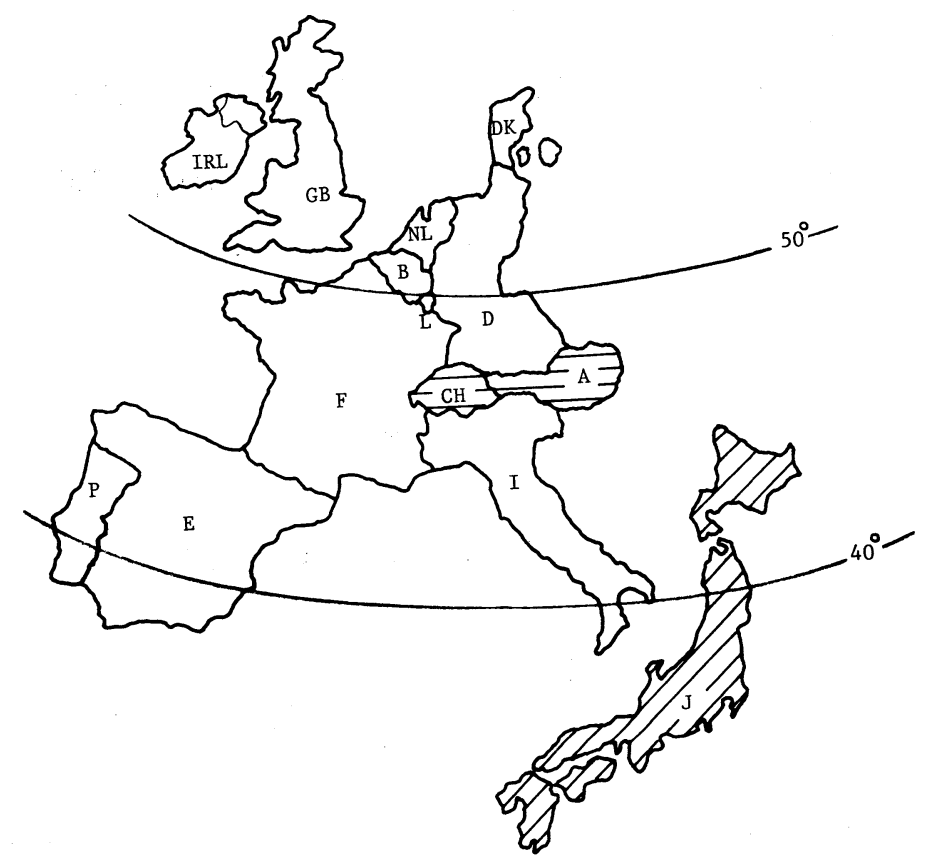

図一｜西ヨーロッパ略図

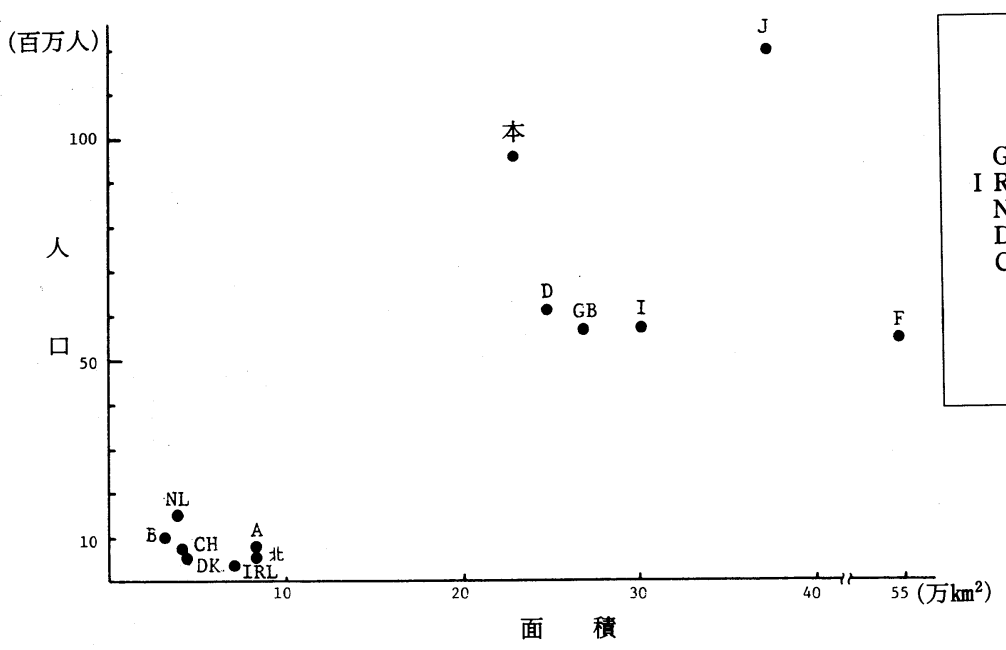

図一2 国土面積と人口 


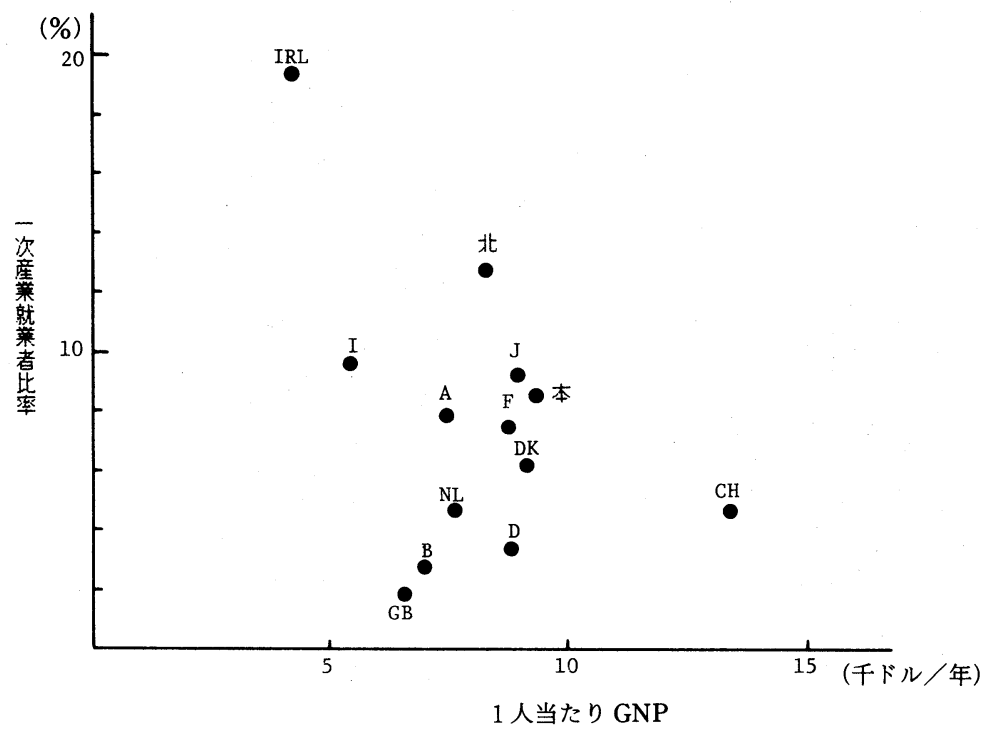

图一3 人当たり GNP と一次産業就業者比率

業者比率を示したあのである。乙れらの指標でみる 限り, ヨーロッパに多くある小国は北海道ときわめ て似かよった状況であるといえよう。

\section{3. 西ヨーロッパのかかえる地域開発課題 ${ }^{11,2)}$}

西ヨーロッパを全体としてみたとき，現今そてに存 在する社会経済上の課題は次の 3 つに要約されよう。 第 1 は 1980 年代に入って顕著となった経済の停 滞である. 1963 年からの 10 年間で EC 全体で年 率 $4.6 \%$ であった経済成長率は 73 年からの 10 年 間では $1.9 \%$ に落ち込み, 特に 81 年〜 83 年では $0.1 \%$ となっいる. ての結果, 失業率は $11 \%$ を 上回り，失業者数は $\mathrm{EC}$ では 1300 万人にあ達する といわれている. 特に, 乙の失業率は 25 才未満の 青年層では $26 \%$ に達し, そのあたらす社会病理 的影響は甚だしい.

第 2 はきわめて低い出生率の結果, 人口の減少と一 層の高齢化が西ドイッなどいくつかの国でみられる ことである. 同時に 1960 年代より増加した域外か らの出稼ぎ労働者を主とする移住者は現在では EC 内だけで 1200 万人に達している. 成長の停滞, 産
業構造変化に伴う就業機会の減少などに対処するた め各国は移住を厳しく制限しはじめているが，家族 の拡大につれ, 移住者人口は增える一方であり, 失 業問題のほか社会同化という点であ新たな社会問題 を生み出している.

第 3 は環境問題である. 日本に比べ土地面積当た りの負荷は小さいとはいえ, 全体として産業活動む 交通むちゅう密でしかも内陸地の多いヨーロッパで は環境污染, 特に大気污染は深刻であり, 酸性雨に よる森林被害が広汎にわたって発生した，同時に環 境保護活動むきわめて活発であり, 一部は政治組織 となり, 環境行政のみならず社会基盤や産業設備へ の投資にも大きな影響を及ぼすようになった。

これらの社会問題, とくに経済停滞の問題はいわ ゆる地域開発上の問題地域でより顕著である。その ような地域は次のような類型に分けられる.

\section{1）工業衰退地域}

織維産業や造船産業などがまず衰微し, その後, 石 炭, 鉄鋼を中心とする重工業地域が衰退したが, そ れらはイギリスのグラスゴー, リヴァプール,カーデ ィフ, フランスのリールやロレーヌ地方, ベルギーの 
中村 :

リュージュ,ドイッのルール, ザール地方などがそれ である. また輸送品目や輸送先あるいは後背圏の変化 に伴って交通上の位置を失い, 衰退をたどる港湾都 市むいくつかみられる. 対アメリカより対 EC 圏へ の輸送に重点が移ったイングランドのリヴァプール や, 東ヨーロッパ圈をその後背圈から無くしたハン ブルグなどがてれである。乙れらの地域は失業率む 他地域に比べて一段之高く, 地域社会の安定性は損 なわれている。

交通基盤の整備はいうに及ばず, 公園緑地の整備 や大学等の新設, 工業団地の整備など新たな産業を 誘致するための種々の環境整備が図られてはいるが, 工業都市という永年のイメージは企業や人口の新規 立地の妨げとなり, 逆に電子工業など新しい産業は ロンドン, パリ, ミュンヘン, ブリュッセルなど大 都市集積に近接した地区に立地場所を求める傾向に ある。

\section{2）大都市都心部}

住環境の改善の遅れた古くからの大都市では, 住民 は所得の向上につれよりよい環境を求めて郊外に移 住し, 都心部では人口, 産業活動の衰退が生じた. 都心 での立地抑制, 郊外のニュータウン開発や外国人労 働者の都心住宅地区への大量流入などが地域産業の 衰退とと屯にての傾向に拍車をかけたといわれている. このような現象はイギリスのロンドン, バーミンガ ム, リヴァプール, グラスゴーから始まり, オラン ダのアムステルダム, フランスのマルセーユ, リヨ ン, 西ドイッのベルリン, ハンブルグなど人ロ規模 で数百万から数十万人程度までの古くからの産業都 市の多くでみられるものである.

都心部の荒廃は都市の活力低下のみならず治安問 題など種々の社会問題をあむたらす．そのため都心の 商業地や住宅の再開発, モールや文化施設の整備な ど都心部の魅力向上のための対策がさまざまに講じ られはじめている. ロンドンの古い港湾地区ドッグ ヤードの再開発は近代的商業地区整備による大都市 再活性化計画の最む大規模なあのであり, 現在その 事業は着々と進められている。 また多くの国では郊
外での住宅地開発を全くやめ, 都心地区の再開発に 都市整備の重点を移している。都心部への人口の誘 致と郊外での緑地空間のこれ以上の減少を避けるの がその目的である。

3）過疎地域

過疎地域の多くは地理的に，あるいは地形的に恵 まれない地域である．地理的に不利な地域とは半島 の突端や島しょ，あるいは異なった政治経済体制の 国との境界線付近のように辺境地帯に属するあのが 主であり,スコットランド, アイルランド, フラン スの西部地域，イタリア南部，西ドイッのシュレス ビッヒ・ホルシュタインなどがそれである．アルプ ス山中やウェールズ地方などは地形的に厳しい条件 下にあり，交通条件にあ恵まれていない．

これらの地域に扔いては二次産業の比率は低く， 永年にわたり人口の流出が続いてきた。近年におい ては各国政府あるいは ECにより各種の地域振興資 金が投入され，過蹯化の大幅な進行がかろうじて止 められているのが現状である.

このような，いうなれば伝統的な人口流出地域に 加えて, 最近では他地域に比して低い生産性の農業 に頼る地域が $\mathrm{EC}$ 域内の他の地域との競争力を保持 しえず，そのため全体が衰微の方向をたどる地域が いくつか現われている．南ドイッやオーストリヤ, スイスでの酪農地帯などがそれである．各国政府の 補助金がかろうじてその地の農業の衰退を抑えている.

以下に颃いては，てうした地域問題に対しての西 ヨーロッパの様々な地域開発政策を示したいが，そ れらのすべてについて言及するのは著者の能力をは るか刧えるものである，そてで，ててでは全ヨー ロッパレベル, 国レベル, 地方レベルの地域開発政 策について顕著な例を二，三取り上げて述べるとと にする。

\section{4. ヨーロッパ共同体（EC）—ヨーロッパ内 の後進地域開発援助}

\section{1 西ヨーロッパ各国の一体性と独立性}

現在の西ヨーロッパの地域開発政策を考えるとき, 
各国を個別にわが国と対比させて考えるのは適切と はいえないだろう. 西ヨーロッパの各国は集まって経 済的には単一の国家と同じょうに機能しょうとして いるし，政治的にあ同じ方向を目指しているからで ある. かと言って，西ヨーロッパ全体をわが国と並べ てみる訳にあいかない，西ヨーロッパの国全体が一 つの国と同様に機能するにはそれらが歴史的に余り にあ多様であり，現在あそれぞれ独立した国として 存在し，個別にその政策を実行する部分むまだ多い からである。

そのため, わが国の地域開発政策と西ヨーロッパの それを対比してみる場合, ある部分は日本と西ヨー ロッパ全体あるいは EC を比べて論ぜられるべきで あるし，あるときは日本とフランス，西ドイッ，オ ランダ等々の各国を並べて議論されねね゙ならない. 加えて, 国内の地方とはいえ歴史が古く, 文化的了 イデンティティーの高いヨーロッパの各地方はしば しば大きな社会的，伝統的特異性と自治権を有して いる．そのためてれらの各地域の地域開発政策む, ある場合にはわが国全体のそれに相応するほど独自 性の強いあのである。

このようにみてくると, 北海道の開発はあるとき はヨーロッパの一つの国のそれと比べてみられよう し，またあるときは各国の各地方と対比されるとと ができると思われる．そこでまず西ヨーロッパ全体 を対象とした地域開発政策として EC のそれをみて みよう。

\section{2 EC について}

EC (European Community：欧州共同体)は 1958 年に拈けるEEC ( European Economic Community ) の発足以来，共同市場を設立し，加盟 各国の経済政策を漸次接近させることを図ってきた。 それにより，EC 全域を通じて各経済活動の調和あ る持続的な発展, 生活水準の向上と安定を達成しよ うとするのであり，そのため具体的には次のような 政策をとることが定められた。

1）商品輸出入における加盟各国（以下各国と記 す) 間の関税, 数量制限等の撤廃
2）第三国に対し共通の関税と通商政策を適用

3）各国間の人，サービス，資本の移動の自由

4）農業部門において共通の政策を適用

5）運輸部門において共通の政策を適用

6）雇用機会を改善し，生活水準の向上を図るた め欧州社会基金を創設

7）新たな資源開発のため欧州投資銀行を設立

8）共同市場が適切に機能するため各国の国内法 の調整

などである。

1965 年には経済共同体 (EEC), 石炭鉄鋼共 同体 (ECSC), 原子力共同体 (EURATOM) が 合体し, 現在の形の欧州共同体 (EC) となる. 当時 の加盟国はフランス, 西ドイッ, イタリー, オラン ダ, ベルギー, ルクセンブルグの 6 か国であったが, その後 1973 年にイギリス, アイルランド, デンマ 一クが，1981年にギリシャが， 86 年にスペイン， ポルトガルが加盟し, 現在は 12 か国が構成国とな っている. その結果, 人口では約 3 億, 域内総生産 であアメリカ合衆国を越える強大な経済圈域となっ ている.

\section{3 EC の地域開発 ${ }^{4)}$}

$\mathrm{EC}$ の地域開発への役割の一つは各国の地域援助 の調整である．EC内の各国が個別に自国産業の強 化のために援助を与えるととは, 各国産業の競争力 を不当に歪めるあのとして規制されている，そのた め各国の国家助成は特定の産業部門でなく地域への 助成が中心となる．その援助む共同市場の原則と相 反しないあのに限定して許される。すなわち，a ） 生活水準が極端に低い地域，あるいは大量の失業者 をかかえる地域の経済開発促進，b）特定の経済援 助や特定の地域の開発を促進する援助で加盟国の共 通の利害を損なうような貿易上の影響が生じない援 助, c ）各国に共通する利益をむたらす重要なプロ ジェクト実施，あるいは各国の重大な経済上の困難 是正のための援助，などである．

そして地域への立地補助む最高補助額がECの「地 域援助計画の調整に関する諸原則」で明確に規定さ 
れ，地域の開発レベルにより次の 4 つに分けられて いる.

1. アイルランド, 南イタリー, ベルリン等：初 期投資額の $75 \%$ まで，または創出雇用 1 人当たり $1300 \mathrm{ECU}$ (ECU：ヨーロッパ通貨単位)

2. フランス，イタリーなどの政府指定開発地域： 投資額の $30 \%$ ，または雇用 1 人につき $5500 \mathrm{ECU}$

3. 西ドイッの東側国境地域, デンマークのユト ランド半島など： $25 \%$, または $4500 \mathrm{ECU}$

4. その他のすべての開発地域： $20 \%$ または $3500 \mathrm{ECU}$

てのようにして各国が個別に行う地域開発援助に 規制を加えると同時に，EC は独自に地域開発基金 (Regional Development Fund)をむち，各国の 地域開発にかかわる支出を補助している. ての基金 は EC の独自の財源より支出されるあのでその額は EC の一般予算 220 億ECUの $13 \%$ を占めるあの である，ての基金による補助は先に述べられた各国 の企業立地補助率の範囲内でそれをさらに補助する 形をとるか, 産業振興に資するインフラストラクチャ 一整備への補助の形をとる. 量的には後者のインフ ラ補助が $3 / 4$ を占めている.

乙の基金は付加価値税や域内への輸入関税などを 財源とするECの一般予算より支出されて, 先に述 べたような域内各国の低開発地域へ補助される。し たがって域内の発展した国や地域から低開発の国や 地域にての補助金の形で移転がなされることになる。 てのような基金により ECは独自の裁量により地域 .開発の促進を行うのである.

ECのむついま一つの地域開発への機能は EIB (European Investment Bank)によるあのである. 乙の銀行の活動は 1958 年EEC の創設と共にはじめ られ，国連における世界銀行と同様な性格をあつあ のである. EIB は経済的苦境にある地域の経済への 開発投資, あるいは各国にまたがる産業近代化など への投資を主として行い, エネルギー開発プロジェ クトやインフラストラクチャー建設のプロジェクト あ重要な融資対象である。 また最近では先端技術開
発を行うべンチャー事業等への融資を通じて EC 全 体の経済の再活性化を図ろうとしている.

てのようにEC内では国を越えて, 開発を必要と する域内の地域のために種々の助成がなされてい る。域内各地域の健全な調和のある発展は EC 全域 の持続的な成長と安定性の確保に役立つと考えられ ているからである.

直接に地域開発を目論んだのではないが，ECの 政策で地域，特に農村部の振興に大きな影響をむつ あのに農業政策がある.EC内の農業は各地方の気 候, 土境など生産条件の差や農業構造の相違のため その生産性に大きな差がある，たとえばフランス農 業はドイッのそれに比してはるかに高い生産性を有 する．したがって域内の共同市場化による農業産品 の自由な流通は生産性の劣る地方の農業を衰退させ, その地方を疲弊させることになる。

ECの農業共同市場は域内に統一価格を敷いて自 由流通をさせると同時に, 価格がある限度以下に下が る時は介入機関を通じてその農産品を一定の価格で 買い入れて農家に対して所得保証を与え，域外に対 しては輸入品と域内価格の差を課徴金として徴収し, 域内価格の安定を図るという仕組みをとっている.

生産性の低い地域の農業生産の維持のためには比 較的高い価格の設定が必要であり, てれはその地域 の農業への補助金と同様に機能するととになる。し かしその結果, 生産性の高い地域は過剩な生産を行 い, その生産物の買入のための支出は EC 財政に大き な負担を課することになり,わが国の食管制度とほぼ 類似の困難に陥っているのである．乙のような形で の農産品共同市場はECのかかえる最も大きな問題 の一つであり, 早晚大きく変革される可能性ああり うるが, その場合競争力の弱い農業をあつ地域を如 何に経営するかが大きな課題となる.

\section{5. ドイツ連邦共和国一一高い質の生活環境によ 了地域発展}

\section{1 西ドイツの地域問題 ${ }^{3), 5)}$}

この国はわが国の本州に四国を合せたあのにほぼ 
西ヨーロッパの地域開発一北海道開発を考えつつ一

近い面積を有し，その人口密度もわが国のそれより は低い $\left(250\right.$ 人 $\left./ \mathrm{km}^{2}\right)$ が, 大差はない. 産業の生産力 や構造等多くの面であわが国と比較的類似した状況 にある国よいってよい. ただ, 西ドイッ(ドイッ連邦 共和国 ) は大都市への人口の極度の集中がない数少 ない国の一つであり,乙こには東京やパリ, ロンドン といった大都市はなく, ハンブルグ，ミュンヘン， フランクフルト, ケルン, シュッットガルト, とい った札幌, 仙台, 広島, 鹿児島, 新潟クラスの都市 が全国に点在している（図ー4）。乙のような都市 構成がこの国で成立しているのは，a）歴史的にみ て 1872 年のドイッ統一までは分立した小国家群で あったてと，b）ベルリンが分割され孤立し，行政, 産業, 文化の一大中心地を無くしたこと, c ）戦後 は連邦主義であり各州に大幅な自治権が与えられて いること,などいくつかの理由があげられよう。ク リスターラーは南ドイッの都市分布の状態を分析し, 有名な中心地理論として集大成したが，乙の中心地 理論がまたドイッの国土計画の理論的中核として常 に機能し, ほぼ同規模な集積をもつ都市の国全体に わたる一様な分布とすべての都市の多段階の階層的

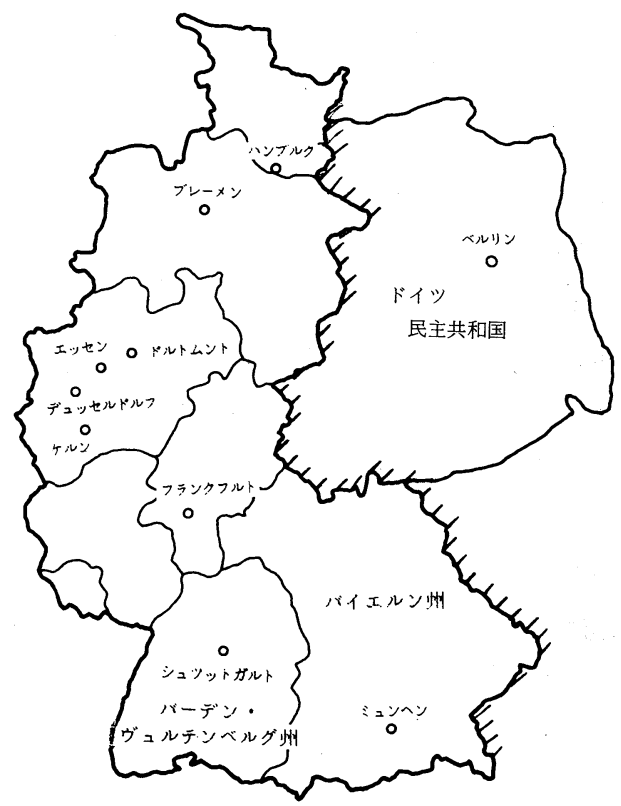

図一 4 ドイツ連邦共和国
配置へその発展を導き, またそれを可能とする高速 道路をはじめとする交通体系を作り上げてきたとい える，それゆえ日本やイギリス，フランスに顕著な ような巨大都市への集中による過密の問題はほとん ど存在しない. 産業の高度化が進み, 所得水準む高 く, 厳格な土地利用規制で確保された生活環境は一 般に快適で美しく, 約 $8000 \mathrm{~km}$ の高速道路をはじ め鉄道, 空港等の交通施設や住宅, 公園, 上下水道 等のインフラストラクチャーの整備も世界の最高水 準にあるといってよい.

このようにきわめて高い福祉の水準を満たしたこ の国ではあるが，地域計画的な課題はいくつか抱え ている．近年の国土計画の重点施策プログラムでは 西ドイッにおける地域開発上の問題とすべき地域, すなわち重点的な開発投資等を図るべき地域として 以下の地域を上げている.

1. ベルリンおよび東ブロック境界地域

2. 過疎地域

3. 古くからの工業よりなるちゅう密地域

4. 環境負荷の大きい地域

5. 自然資源保全地域

6. 農林業地域, 水資源汃ん養地域, 景観保全地 域，鉱物資源地域

これらの地域では産業の衰退, 失業の増加, 人口 の減少, 環境問題の発生などが生じているのである. 現在の西ドイッで失業と並ぶ深刻な社会問題は環 境問題, 特に森林の被害である.乙れは産業, 自動 車交通や暖房などによる大気污染に基づく酸性雨に 主として起因するといわれている. 工場等の排出ガ スの低イオウ化や高速道路の速度制限区間の増加な ど部分的な対策を講じてはいる. しかし，その原因 が必ずしも明らかでないことに加えて, 污染源のか なりの割合は隣接国にあり, また自動車の排ガス規 制の強化も EC内での合意になかなか到達できず, 一国だけでの対策強化では有効でないことなどああ って森林枯死に対する具体的な対策はその問題の深 刻さの啓蒙や緑破壊への反対運動の激しさに比べる とまだ遅れているといえる。 
中村：

失業の発生や人口減少の問題は西ドイッの 8 つの 州执よび 2 つのハンザ都市州と西ベルリンに执いて多 かれ少なかれ地域的に存在するのであるが，てれを 州単位でマクロにみると問題を多く抱える北部の諸 州と，それがより少なく繁栄の途をたどる南部の州 との違いが目立つ。そてで以下に打いては北海道に ほぼ匹敵する人口や面積をむつ南ドイッの 2 つの州 すなわちバーデン・ヴュルテンベルグ州とバイエル ン州についてみてみよう。

\section{2 バーデン・ヴュルテンベルグ州，バイエル ン州の発展とその理由 ${ }^{6)}$}

ドイッの工業は, 従来, 北部ドイッのルール地帯や ラインランドなどが中心であり，そこに産出する石 炭やハンブルグ, ブレーメンの港あるいはロッテル ダムのユーロポートを経由する原材料を使っての重 化学工業が数多くててに立地していた。しかし, 近 年のエネルギー源や産業構造の変化はこれらの従来 からの工業地域を衰えさせ，人口の減少と高い失業 率( ノルトライン・ヴェストファーレン州 $11 \%$, ブレーメン $14 \%$ ：1985 年)をむたらすととにな る.

一方, 南部の諸州たとえばバーデン・ヴュルテン ベルグ州は従来, 開発の遅れた地域であった。山が ちで土地が狭いこの地の住民は勤勉さでは有名で多 くの芸術家, 科学者, 政治家などを輩出したが貧し く,アメリカ大陸をはじめとして国外への人口流出 あ多いとてろであった。しかし現在は州都シュッッ トガルトとその周辺都市を中心として機械加工や自 動車, 電子工業が数多く立地し, 特に最近では電子 産業をはじめとする先端技術型の工場進出が盛んで ある.その結果，ての州の一人当たり所得はドイッ 一であり, 失業率む $4.9 \%$ \%ヨーロッパで有数の低 さである. ミュンヘンを州都とするバイエルン州あ 事情はほぼ同じである.

戦前よりシュッットガルトのダイムラーベンッ, ミュンヘンのメッサーシュミットなどいくつかの高 度機械加工型の工場が立地していた。しかしてれら
の州が近年特に近代産業地域として大きく発展した 理由として次のようなあのが挙げられている.

第 1 は, 市町村が産業誘致に熱心であり, 各種の 助成を行っていることや住民は勤勉でかつ柔軟なて とである，既存の工業に安んじ，また硬直的である といわれる北とての点でまず対照的であるとされる. 第 2 は, シュッットガルト, ミュンヘン, カールスル 一エなど数多くの大学の存在である. 州政府あ大学 と産業界の協同での研究開発を推進する体制をとっ ており，乙れが先端技術指向のベンチャービジネス を惹きつける大きな要因となっている，工業地帯の 労働者や住民が進歩的思想を抱くようになるのを恐 れたプロイセンが大学を設けなかったといわれるル 一ル地帯との一つの大きな差であろう．そして第 3 は豊かな生活・文化環境である。長らくバイエルン 王国の首都であったミュンヘンは南ドイッの歴史的 中心であり，今あ全ドイッの文化の中心であるし， シュッットガルトも有名な劇場, 音楽会, 博物館等 にとと欠かない．乙の 2 つの首都のほかニュルンベ ルグ, カールスルーエをはじめとして文化的色彩の 強い多くの中小の都市が存在する. 加えてバーデ ン・ヴュルテンベルグにはシュバルッバルトやボー デン湖が, バイエルンにはチロルにつながるバイエ ルンアルプスや数多くの湖が存在し、レジャーやリ クリエーションの適地はきわめて豊富である。乙れ らの生活上の魅力は多くの人々にての地に定住する ことを指向させ，それがまた産業立地の誘因となっ ている. 空港がよく整備され, アウトバーンが四通 八通しているての国では交通条件のような産業立地 条件は全国ほぼ同等である。そのためこてに挙げた ような要因が地域の成長に大きな影響を及ぼすので ある.

現在, この国の抱える一つの大きな社会問題は人 Пの減少である。 1960 年代中期を境に出生率は大 きく低下し, 再生産率では 0.8 以下を続けている. そのため 1975 年で 6200 万人であった人口は現 在では 6000 万人に減少し, 50 年後には 4000 万人以下になるとも予測されている。 てのような中 
西ヨーロッパの地域開発一北海道開発を考えつつ一

でこの南部 2 州は北からの流入もあって今のとてろ 人口減がほとんど生じていない.

以上のような南の発展に対して,ルール地方をは じめとする既存の産業集積地域や連邦政府による開 発重点地域に指定されている各地す, 種々の地域振 興策を講じている．乙れらはビジネスパークやテク ノ(サイエンス) パークの建設と企業誘致, コンベ ンションやメッセ施設の整備, 音楽祭をはじめとす る各種のイヴェント開催や文化観光施設づくり, 都 心再開発や余暇公園建設など, わが国と同様多岐に わたる.

地価の高騰など発展阻止要因が見られる南の各州 や自治体も上と同種の政策はむちろんのとと, 外資 企業や外国からの観光客の誘致にあ力を注ぎだして いる.

\section{3 西ドイツの国土計画, 地域計画, 都市計画 の体系 ${ }^{3), 8)}$}

西ドイッを旅するとき, 我々はこの国の整然とし た都市や村落のたたずまいに, 美しい森林や畑の連 なる田園風景に, そしていかにも効率的な生産施設 や交通施設の配置に感心し, それと同時にてのよう な土地利用や施設配置を作り上げた計画体系に興味 をあつ. そてで，ててではきわめて簡単にではある が, ドイッの地域整備の計画体系すなわち, 空間計 画体系について述べておく。

西ドイッの物的な計画体系の特徴は国土計画から 建築計画に至るまでが一つの体系となっているとと である。

連邦の国土計画法による国土計画 ( Raumordnu$\mathrm{ng})$ は連邦国土計画プログラムの形で表わされ, 全国土にわたって国土政策上重点的に整備すべき地 域を区分指定し,さらに各種インフラストラクチャ 一の整備目標をかかげる. 全国は 38 の地域に分け られ, 各地域は一つの上位中心地をあつ。

各州はそれぞれの州開発計画法にもとづき州計画 ( Landesplannung) として州開発計画プログラム を作成する. このプログラムでは多段階の中心地と 発展軸より成る空間構造を設定し, その発展の目標
とそのためのインフラストラクチャーの整備計画を 示す. 連邦政府が個別のプロジェクトに関与するて とが少ないての国では個々の開発プロジェクトの計 画はこの段階で具体化される.

州開発計画法は州をいくつかの広域圏 (Region) に分け, ての地域を対象としてさらに具体的な整備 計画を示した広域圈開発計画がつくられる。乙れは 総合的, かつ具体的な地域計画の単位としては各市 町村では小さすぎるためであり, 1920 年代のルー ル炭鉱地方定住組合による広域計画以来の伝統をむ つあのである。乙の段階の地域計画は広域圏計画 ( Regionalplannung) と呼ばれ, 中心地の圏域, 産業, 社会, 文化的施設の整備目標, 景観, 交通, 住宅, 保健, 余暇等の各分野に打ける将来計画など が示される.

市町村の計画は連邦建設法 (Bundesbaugese$\mathrm{tz}$ ) 亿基づく市町村開発計画 (Stadtentwicklungsplan) と建設指導計画 (Bauleitplan) より成る. 市町村開発計画は市町村の人口, 経済活動等の現状 と将来目標値を示し, 各種基盤施設の将来計画とそ の優先度, 必要な資金を表わすあのであり, 動的か つ総合的な計画として, 静的かつ純物的な計画であ る建設指導計画に直接反映されるあのである．建設 指導計画は土地利用の用途指定および公共施設を表 示する土地利用計画 F-Plan (Flaechennutzungsplan ) と区画でとに用途, 容積率, 建物の形態, 建 築線などを細かく指定する地区詳細計画 B-Plan (Bebauungplan) より成り立っている.

西ドイッの空間計画制度はこのように連邦レベル でかつ総合的な国土計画から市町村における地区詳 細計画に至るまで統一的な体系をなしている。しか し, ての体系的な計画を余り高く評価しすぎること は問題である. 個別具体的に生まれ歴史的に発展し てきた地区詳細計画などの都市計画制度と上からの 国土計画, 州計画の間は必ずしあ整合的ではないと の批判あある. 事実, 地方分権, 住民の自由意志尊重, 私経済への可能な限りの不介入を国是とするこの国 では, 産業政策的な地域総合開発政策に余り見るべ 
中村:

きものはなく, 逆に下位の計画がより大きな意味と 拘束力をむって抢り, 上位の計画は下位からの積み 上げと見なすべきすのが通例である，乙のような強 力な下位計画の典型が住民参加により市町村で作成 され土地利用を詳細にわたり強力に規制する BPlanである。はじめに述べた西ドイッの整然とし た景観はこの成果の一つの表われであるといえる.

\section{6. アイルランドー外国企業誘致による開発一}

\section{1 苦境にあったアイルランド}

アイルランドはイギリス本土の西側にある面積約 7 万 $\mathrm{km}^{2}$ の島国で, アングロサクソン系の英国とは 異なりケルト系でかつカソリックの住民約 300 万人 が居住する. 第一次大戦後の 1922 年に独立するま で長らくイギリスの支配下にあり, 遅れた農業国で しかあ気候, 土袞ともに恵まれないての国は西ヨー ロッパの諸国に比して一段と貧しく, 常に海外への 大量の人口流出と失業に苦しんできた。一時期 850 万人もあった人口は飢餓やアメリカなどへの大量移 民により 1961 年には 280 万人にまで減少する. そ してアイルランド系のアメリカ人の人口は本国のア イルランド人の 4 倍にあ達するといわれている。 て の窮状から脱皮するためにアイルランドは独立後 農業国から工業国へ転換するととを企図し，保護関 税政策の下で工業化を試みたがほとんど成功をみな かった。 人口 300 万人足らずの小規模な国内市場 では近代産業を支えることは到底不可能であったた め, アイルランドは 1950 年代に入ると自由貿易政 策に転換し，世界という大きな市場を相手とする工 業を発展させようとする，そのため輸出品を生産す る工業の育成を外国企業の投資を通じて図ろうとし， 大々的な地域開発, 産業開発政策がとられることに なる。

\section{2 外国企業の立地 ${ }^{9)}$}

かくして, アイルランド産業開発庁 (IDA, Industrial Development Authority) が設立され，てれ を通じて工業立地のための基盤施設整備や工場建設 への特別融資や補助金をはじめ，のちに述べるよう
な種々の広汎な優遇政策が講じられた. 1973 年, ECに加盟を認められるが，乙れはアイルランドの 産業開発に図り知れない効果をむたらした。農業部 門においてあ市場が拡大するとともに EC の共通の 農業政策により主要農作物の価格が大きく改善され た。 さらに大きいととにはアイルランド工業が EC という広大な市場を直接に対象とすることになった ことである.

EC は各国政府が個別に行う産業助成政策に制限 を加えている．それは各国の個別の援助は域内産業 の競争力を不当に歪める可能性をむつためである. しかし生活水準のきわめて遅れた地域など域内の低 開発地域に扔いてはある一定の限度までの投資援助 が認められている．そのため後進のアイルランドは この限度いっぱいの援助を行い, 特に外国系企業の 誘致を図っている.

その場合, 誘致を歓迎すべき企業立地プロジェク トとして次のようなあのを挙げている.

1. 高い市場成長率

2. 長期安定性

3. 高度熟練労働力の雇用を要すること

4. 国内所得の向上に貢献しうること

5. 輸出性が高いとと

6. 新規雇用創出に要する資金が小さいか, 必要 資金が大きい場合は国内での波及効果が大きい こと

てのような企業立地に際しては次のような種々の 優遇制度が設けられている。たとえば,

1）法人税の減税：一般の法人税率は利益の 45 \%であるのに対して $10 \%$ に減免

2）固定資産投資への補助：土地, 工場建物, 設 備等への投資に対して後進地域では最高 $50 \%$ まで補助

3）研究開発に対する助成, 新製品開発などのた めのR \& D に対して研究費の $50 \%$ までを助成

4）人材養成, 技術訓練への補助金

5）工場用地の優先的提供

この結果, 1960 年から 78 年までの 19 年間に了 
イルランドには日本を含む各国から 700 社に及ぶ企 業が進出し, 工業製品の輸出比率は $50 \%$ を越え, 同国のGNPに占める工業の割合は $35 \%$ を越える ようになり農業国から工業国へ脱皮した。工業発展 によりアイルランドはこの間年率 $10 \%$ 近い経済成 長率を示し, 新しい雇用を創出し，100年以上にも わたって続いた人口流出に歯止めをかけて僅かなが ら人口の増加をあたらすととに成功した。

アイルランドの工業化のこのような成功は海外企 業の積極的な誘致策, 英語がアイルランド語と共に 公用語であるとと，EC加盟により西ヨーロッパ 全域を市場としたこと，まだ生活水準が低く人件費 が安いことなど多くの理由によるあのである.アイ ルランドは過去に有能な人材が国外に流出し, 乙れ がまた同国の停滞を招いた経験にかんがみ，現在で は若者の定着と高等教育に力を入れている.

しかし近年, ストライキの多発, 交通通信施設等 インフラストラクチャーの整備不足なども妨げにな り，新たな産業立地は余り進展しなくなってきたと いわれている.

\section{7. オーストリヤ— 観光開発による地域の安 定化}

\section{1 オーストリヤの産業 ${ }^{10)}$}

オーストリヤは国土面積が 8 万 $4000 \mathrm{~km}^{2}$ で人口
が 750 万人であること, 国土面積の $40 \%$ を森林が 占めており積雪地も多いとと, 一, 二, 三次産業就 業者数の比率がそれぞれ 10：40：50\%であり, 1 人当たり所得は $\$ 8900$ ( 1982 年)であるて となど, 内陸国と島であることの違いを除けば北海 道ときわめて似かよった環境にある国といってよい. 加えて, 図一 5 にみるように都市構成も, ウィーン という中心に全人口の約 $20 \%$ が集まり，乙れも札 幌に集積する北海道と似ているといえる．ただ大き

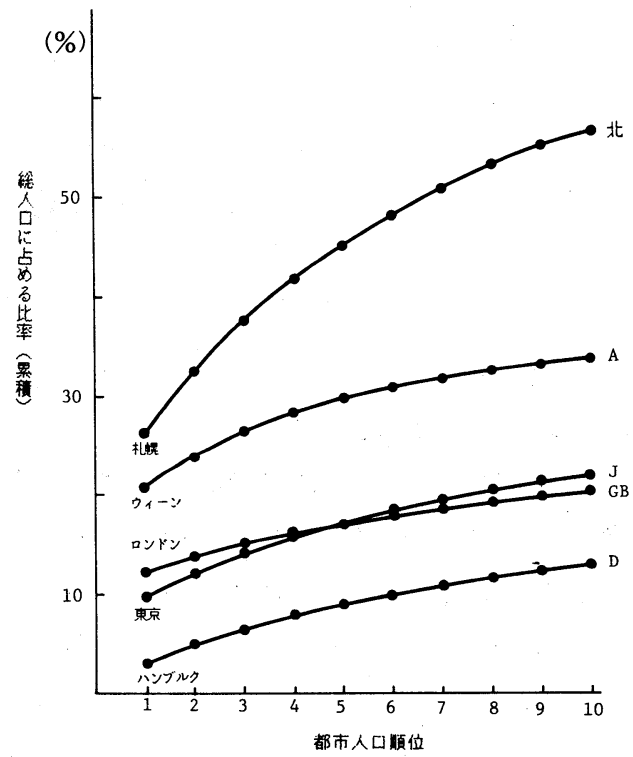

図一 5 人口の大都市集積

総人口中に占める各都市の人口（ 10 位まで )

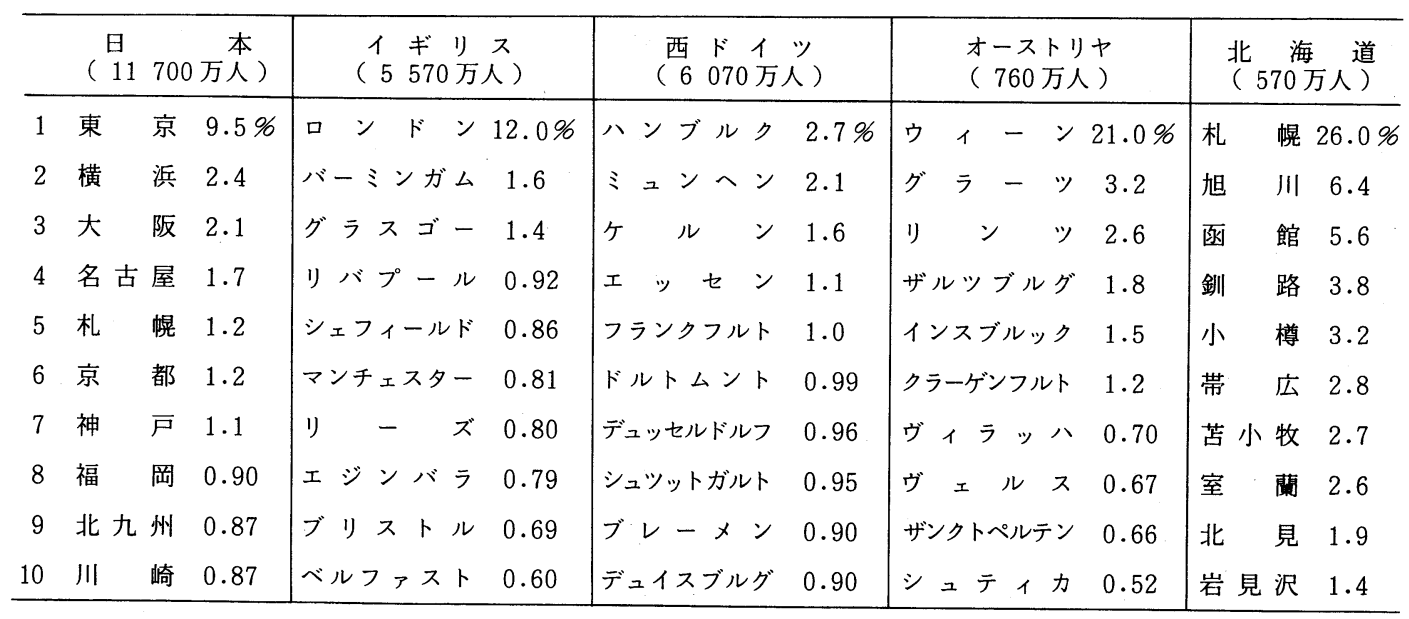


中村 :

な違いは, 今でてそてのような小さな国となってい るが，かつては 700 年間にわたりヨーロッパに君 臨したハプスブルグ家による大帝国の中心地域であ り, 中世以来の史跡, 建造物をはじめ多くの文化遺 産を抱えていることである。

次に産業についてみでよう.オーストリヤは鉄 鉱石を産出し，てれをあとにして鉄鋼業が栄え今で あ鉄鋼業はこの国の工業の中での最大の部門となっ ている．鉄鋼の 2 大生産都市リンッとドナウッッの 名をとって LD 法と呼ばれる酸素吹上製鋼法をはじ め，乙の国で開発された鉄鋼関連技術む多い，その ほか製造業では化学，機械関連す盛んである。また， 建設業は就業者数で全産業の $10 \%$ 近くを雇用する 大きな部門であり，世界市場でも多くの工事実績を 挙げている。 てれはての国の地形的特性からくる必 要性が生み出した水力発電やトンネル建設技術に, 鉄鋼業の加工技術が加わって作り上げられた総合技 術力によるあのであるといわれている。

ての国の緑濃い森林, 牧場や農場の景観からは農 林業がきわめて大きい産業上のシェアーを占めてい ると想像されようが, その生産額はGDPの約 $4 \%$ であるにすぎない。しかし食糧の自給率は約 100 \%であり, 東北部等の平地では穀類，とうあろてし， てんさいなどが, 山岳地帯では牧畜, 酪農, 林業が 盛んでての点でも北海道とよく似ている.

この国の産業で特筆されるべきは観光業である.才 ーストリヤの経済にとって外国人観光客のもたらす 外貨は大きな意味をむっており，1983 年における オーストリヤの観光業による外貨獲得額は 950 億シ リング（約 1.4 兆円）で，乙れはGDP（1 兆 2000 億シリング) の約 $8 \%$ に相当するものである。ま たこれはオーストリヤの貿易収支の赤字の $60 \%$ 以 上を補っており，輸出総額の約 $20 \%$ に当たるあの である．産業別にみてあ観光部門のての外貨獲得額 は第 2 位の機械 ( 830 億シリング, 1983 年), 第 3 位の鉄鋼（ 240 億シリング, 1983 年 )を淩駕す るものである. ちなみにての額はわが国のカメラ, 顕 微鏡など光学機器の輸出額にほぼ匹敵し, また北海
道に抢ける年間公共投資総額 (約 1 兆 5500 億円, 昭和 59 年度)に近いむのである.さらに, 観光業の ほか関連産業での生産を加えると外国人観光客に起 因する生産額はGDPの $10 \%$ に達しているといわ れている。

\section{2 地域開発策としての観光産業助成}

てのように，観光はオーストリヤ経済に大きく寄 与すると同時に，都市と地方の両者において雇用を 吸収し，人口を安定させ生活の水準を高めるのに大 きく役立っている．観光産業がオーストリヤでかく あ発展したのには次のようないくつかの理由を挙げ うる。

第 1 は自然環境であり, 美しい森林と牧草地, 水 河をむつ高山と深い湖，夏の長い日照と冬の積雪な どは美しい景観と素晴らしいレジャ一環境を提供し， てれがすでに前世紀初頭からイギリス人をはじめと するヨーロッパ各地からの観光旅行者を招いた。

第 2 は豊かな文化遺産である。 ハプスブルグ家を 頂点にする大帝国の築きあげた文化遺産は城や宮殿, 寺院から音楽，民族衣裳や舞踏に至るまで実に豊富 であり, てれがまた観光魅力を形成する.

第 3 は交通施設をはじめとするインフラストラク チャーの完備である. 8 万 $4000 \mathrm{~km}^{2}$ の国土にウ ィーンのほか国際線も乗り入れる 4 つの空港, $1200 \mathrm{~km}$ の高速道路, 複線・電化が多くを占める $5700 \mathrm{~km}$ の鉄道, $3800 \mathrm{~km}$ の鋼索軌道扰よび リフトが整備されており，国外からの来訪にあ国内 移動にもいたって便利である. また上下水道, 学校, 病院, 都市公園, 文化施設等も充実している.

第 4 は多種多様な観光振興政策を熱心に進めてい ることである．上述のインフラストラクチャ一整備 あその一つであろうが, より直接的な振興策は観光 産業助成, 各種イヴェント開催, 外客誘致活動など である。

観光産業助成の一つの典型は民間による観光施設 整備のための投資に際して連邦政府通産省などを通 じて行われる利子補給である。乙れは会議場, 屋内 スポーツ施設, モールやショッピングセンターとい 
った公共的な施設の整備から，ホテルやペンション， 民宿など宿泊施設の改善のための，たとえばバスや シャワーの設置, 調理場の改修や暖房の改善のよう な小さな設備投資に至るまで，投資総額の約 $3.5 \%$ が, 連邦より $2.5 \%$, 州より $1 \%$ の分担で利子補給 として助成されるあのである.

毎年夏に開かれるザルッブルグ音楽祭は世界的に 著名であるが, このほかにも各地で音楽祭, 演劇祭 をはじめ見本市, 国際会議など多くの催しがなされ， 各国より参加者を集めている。乙れらの催しのため の施設は一般に, 自治体により整備され, また催し の開催にも各種の便宜や助成が与えられる. 国際機 関の設置や国際会議の開催には国を挙げてきわめて 積極的である、特に, ウィーンは国際会議を従来よ り数多く開催し, 戦後は世界で第三の国連都市とし て国際原子力委員会 ( IAEO), 国連工業開発機関 ( UNIDO) や石油輸出国機構 ( OPEC) など多く の国際機構の本部を誘致している.'ドナウ河畔のウ ィーン国際センター（UNO City）には, 現在, 世 界最高級の国際会議場オーストリヤ・センター・ウ ィーンが建設中である.

外国人観光客の誘致のために連邦政府と州政府お よび民間より成る第三セクター機関としてオースト リヤ観光局が設立されている．乙の観光局は東京を 含め世界 20 か所に国外事務所を設け，乙こを中心 にオーストリヤ観光に関する広報宣伝や観光旅行の 斡旋など幅広く観光客誘致のための活動を行ってい る.

これらの積極的な観光振興政策と同時に, 最大の 観光資源であり，かつまた国民的資産である自然環 境亡歴史的建造物や文化財の保全に国を挙げて最大 限の努力を払っている.

\section{8. 北海道開発に際して}

北海道の地域開発は難しい局面を迎えている．た だでさえ立地の少ない製造業は鉄鋼, 造船等構造不 況型のあのが多く, 今後の生産は多くの上昇は期待 しがたく, 農業は酪農, 米等の生産物は過剩生産気味
であるし, 生産額て製造業を上回る建設す財源難によ る公共投資の実質減により頭打ちである. 加えて, 炭 坑の閉山, 北洋漁業の規制による水揚げ減など地域 産業は苦境にあり, 失業率む全国平均を越え, 今後 より深刻化する気配むある。乙のような経済情勢に あ影響され，また生活, 文化等のより高度化し集積 した機会を求めて, 人口は道内では中心都市へ, さ らに道外では首都圈等へと移動する傾向をまだ続け ている.

てのような事情はヨーロッパにおいてもきわめて 顕著なあのであり, 多くの場合, 北海道よりなお一 層深刻である，造船のグラスゴー, 石炭のウェール ズ, 鉄鋼のルールやザール, 港湾都市のリヴァプー ルなどは北海道の問題よりさらに深くかつ大規模で あるし, 過剩でしかむ域外との競争力に劣る農業や 工事の減少が著しい建設業も多くの問題を抱えてお り, 全体として高い失業率と経済, 社会の活性不足 に苦しんでいる.

このような中にあって, これらの国や地域に扔い ては低成長と財政制約のあとで新たな開発戦略を見 つけ, 現状の苦境から脱し安定したより豊かな社会 を実現しようと試み，既に示してきたようなさまざ まな方策をとっている.すなわち，

1. 社会基盤施設整備への補助

2. 企業の設備投資への補助

3. 立地企業への低利融資, 法人税の減免

4. 外資系企業の誘致

5. 産学協同の推進, ベンチャービジネスの育成

6. 大学の拡充 ・ 創設, 人材の地域内確保

7. 生活環境施設の整備

8. 土地利用の規制, 景観の保全

9. 都心地区再開発, 再活性化

10. 余倨・観光施設, 緑地の整備

11. 文化施設の整備, 文化的イヴェントの開催, 見本市や会議の開催

12. 観光基盤施設の整備, 観光産業の育成, 外国 人観光客の誘致

13. 農業産品の価格安定 
14. 小規模地場産業の育成

など多岐多様にわたる. これらのうちの多くは程度の 差てそあれ北海道の地域開発に際してとり入れられ ているあのである。ただてれらの中にはより徹底し た形で実施すべきであろういくつかの施策む示唆さ れているように思われる. たとえば工場の新設立地 に対しての設備投資への助成, 先端技術産業の立地 のために産学協同の推進, 地域定住の魅力増加のた めの生活環境の一層の整備, 道内観光産業の国際化 などがそれに当たるのかもしれない.

北海道のおかれた条件はヨーロッパのこれらの国 や地方以上に厳しいものあ少なくない. 気候条件の 酷しさはヨーロッパ以上であるし, 社会資本や文化 の蓄積は永年にわたって培かわれてきた彼地に比ぶ べきあない. 今後とあこれらの蓄積に力を傾倒する ことが必要であるととはいうまであないし，上に示 されたような種々な地域振興政策も精力的に試みな ければならない.

北海道は乙れまで独自の意図と構想で積極的な地 域開発政策をとったことは少ないし，世界を対象之 し能動的に働きかけたことも多くはない. 北海道は ここで示されたヨーロッパの国々と同様に一国を形 成する力をもった地域である．独自性と国際性に富 む新たな地域開発政策がこの地の潜在的能力を引き 出す可能性むまた大きいといえるだろう.

\section{参考文献および資料}

1）小林 一 : ヨーロッパの地域経営システム, 「地域開発」，1979 年 6 月～1979 年 12 月.

2) R.H.Williams : Planning in Europe, Geage Allen \& Unwin.

3) Akademie für Raumforschung und Landesplannung: Grundriss der Raumordnung Curt R. Vincentz Verlag.

4）JETRO シリーズ：欧州共同体，日本貿易振興 会

5) Unterrichtung durch die Bundesregierung fuer 10. Wahlperide Deursches Bundestags: Programmatische Schwerpunkte der Raumordnung.

6）西独, 仏，スイスの地域政策，財）日本経済調 查協議会, 1986 年 2 月.

7)'祖田 修: 西ドイッの地域計画, 大明堂, 1984 年.

8）ハルムート・ディーテリッヒ，ユルゲン・コッ ホ著, 阿部成治訳 : 西ドイツの都市計画制度, 学芸出版社, 1981 年.

9）JETRO シリーズ：アイルランド，日本貿易振 興会.

10）ARCレポート1980：スイス，オーストリア, 経済・産業の現状と動向, (財) 世界経済情報サ ービス ( WEIS ). 